International Journal of Physical Sciences and Engineering
Available online at www.sciencescholar.us
Vol. 5 No. 3, December 2021, pages: $44-51$
e-ISSN : 2550-6943, p-ISSN : 2550-6951
https://doi.org/10.53730/ijpse.v5n3.2941

\title{
Energy Planning with Renewable Energy Sources
}

\author{
CrossMark
}

Félix Antonio Solórzano Narváez ${ }^{a}$, Edgar Iván Moreno Castro ${ }^{b}$

Manuscript submitted: 18 October 2021, Manuscript revised: 09 November 2021, Accepted for publication: 27 December 2021

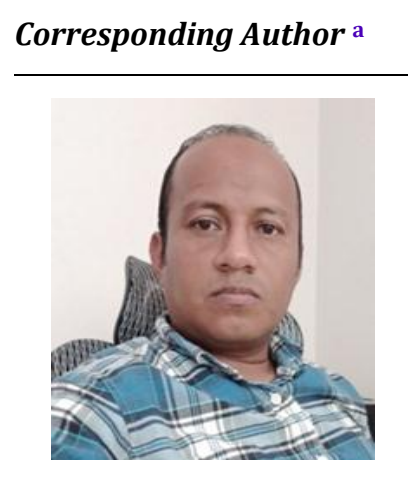

Keywords

climate change;

electricity grids;

energy;

environment;

technologies;

\begin{abstract}
The urban energy model is based on imports from external sources. The continuous increase in energy demand due to population growth and development implies increasing resource requirements. The alternative is to use renewable energies that take advantage of urban resources. The diversity of typologies of cities in terms of resources, demands, architectural conditions, infrastructure, or density, makes a specific analysis necessary. This work identifies fourteen factors concerning the planning process that would allow choosing the most appropriate technology for a given city. Through consultation of experts, the existence of the resource is defined as the most prevalent factor, followed by economic conditions; On the other hand, it is detected that environmental aspects such as global warming, eutrophication, or acidification, are the least incidents when selecting technologies.
\end{abstract}

International Journal of Physical Sciences and Engineering (C) 2021. This is an open access article under the CC BY-NC-ND license (https://creativecommons.org/licenses/by-nc-nd/4.0/).

\section{Contents}

Abstract

1 Introduction.

2 Materials and Methods

3 Results and Discussions

4 Conclusion

Acknowledgments..

References...

Biography of Authors.

a Empresa Eléctrica CNEL, Flavio Alfaro, Manabí, Ecuador

b Empresa Eléctrica CNEL, Santo Domingo, Manabí, Ecuador 


\section{Introduction}

The main objective of energy planning is to satisfy the demand of a city, region, or country in the short, medium, or long term, continuously, with a certain quality and price parameters acceptable. In principle, the planning considered exclusively economic criteria for the dimensioning of the energy structure. Traditionally, the costs associated with the production and implementation of the energy infrastructure were the main determinants; subsequently, aspects related to the social and environmental dimension emerged as priorities. Technological advances make it possible to consider renewable energy as an option to change the energy supply model (Ibáñez Martín et al., 2020; Yadoo \& Cruickshank, 2012). At the Habitat conference, the importance of Integrated Renewable Energies in urban development was emphasized (International Renewable Energy Agency, 2016). However, there are no single solutions, given different urban configurations, resource availability, or energy demands. It is expected, then, that its development will be strengthened with the collaboration between municipalities and the study of successful cases. Municipalities normally have the autonomy to plan transportation, land use, buildings, water supply, or waste management, but limited control over energy supply (International Renewable Energy Agency, 2016).

The reduction in costs of Renewable Energies would facilitate the inclusion of energy alternatives within urban limits, encouraging a sustainable urban model (International Renewable Energy Agency, 2016). (Páez, 2010), proposes that, in addition to the use of renewable resources, bioclimatic architecture, energy efficiency, and the implementation of programs that encourage circular urban metabolism to be promoted. Unlike the regional scale, the city must analyze aspects related to architecture, availability of space, or other limitations that prevent the use of the resource. This article explores the factors that could influence the adoption of eleven technologies that use renewable resources available or that come from the city.

Photovoltaic technology seeks to directly convert solar radiation into electricity. Based on the photoelectric effect, the process uses devices called photovoltaic cells, which are semiconductors that are sensitive to sunlight; so that when exposed to it, an electric current circulates between its two faces in the cell. The components of a photovoltaic system depend on the type of application considered (connected to the grid or not) and the characteristics of the installation. An isolated photovoltaic installation is made up of the equipment intended to produce, regulate, accumulate and transform electrical energy (Vázquez-Rowe et al., 2015; Tarroja et al., 2019).

\section{Materials and Methods}

The literature review was applied as a methodology, where it was possible to investigate the existing situation in the province of Manabí to achieve energy planning, from that information the inductive deductive method was used, the anñalis synthesis, in addition to using as a tool the geographic information system for the elaboration of the maps and will carry out the territorial analyzes.

\section{Results and Discussions}

In the mid-1970s and early 1980s, when governments in industrialized countries began to finance gridconnected solar energy programs, they tended to favor large, centralized photovoltaic plants. , instead of small units located on the roofs of buildings. The reason was not due to any other analysis that was not following the dominant trend until then, of generating electricity with large, centralized facilities. Thus, photovoltaic power plants began to be built in various parts of the world. Generally, they are connected to a distribution network and although the effect of saving fuel and reducing the environmental impact is achieved, a good result is not achieved in reducing losses, on the contrary, they can be increased (Battaglini et al., 2012; da Graça Carvalho, 2012). However, many pioneers of these systems were convinced that this technology was more adapted to generating energy in the same place where it was needed. Power plants photovoltaic connected directly to the load in the mode of distributed generation present a group of advantages in relation to the large power photovoltaic networked in the centralized model, among which can be noted the following:

Narváez, F. A. S., \& Castro, E. I. M. (2021). Energy planning with renewable energy sources. International Journal of Physical Sciences and Engineering, 5(3), 44-51. https://doi.org/10.53730/ijpse.v5n3.2941 
It manages to reduce the losses that are inherent to traditional systems (distribution and transformation), it is possible to improve the voltage profile of the network where they are connected, it increases the level of system reliability and the quality of the electrical service, resources can be saved In the investment, by not requiring the acquisition of new transformers, poles and distribution lines, better use of the available space is achieved, they tend to obey simpler technical designs that are more feasible to handle during operation, cleaning, security measures, and protection. o A greater relocation of generation sources is achieved and a greater link between social actors in energy management can be achieved (Clastres, 2011; Aghaei \& Alizadeh, 2013).

\section{Photovoltaic installation}

A photovoltaic is the set of electrical and electronic equipment that produces electrical energy from solar radiation and the technology support equipment. The main component of this system is the photovoltaic generator, capable of transforming the incident light energy into direct current electrical energy. The photovoltaic arrangement (generator) can be made up of panels that are made up of several solar modules and these in turn of several cells or photovoltaic cells. Photovoltaic modules admit both direct and diffuse radiation, being able to generate electrical energy even on cloudy days. In general, the cells have nominal powers close to $1 \mathrm{Wp}$, which means that radiation of $1000 \mathrm{~W} / \mathrm{m} 2$ provides voltage values of about $0.5 \mathrm{~V}$ and a current of about two amps.

\section{Grid-connected systems Grid-}

Connected photovoltaic generators can provide important benefits to distributed generation systems, depending on the characteristics and operating conditions of the electrical distribution network, as well as their location within it, it can be improved the quality of energy in the generation areas contributing the surplus energy to the system, these present different contributions. One of the advantages that the photovoltaic plants connected to the grid have is that the converters or inverters used in these schemes do not have to worry about the problem of unforeseen increases in the load, as the network is in charge of meeting these needs (Kezunovic et al., 2020; Trujillo, 2019). However, the foregoing, the proper sizing of this equipment is a fundamental aspect in the design of the systems based on the output of the photovoltaic generator and the parameters that make the interface with the electricity grid. The province of Manabí is located on the territory coast of Ecuador, has one of the highest levels of incident solar radiation in relation to the rest of the country. Figure 1 shows the map on a chromatic scale with the annual average daily solar potential that affects the province and its main cities.

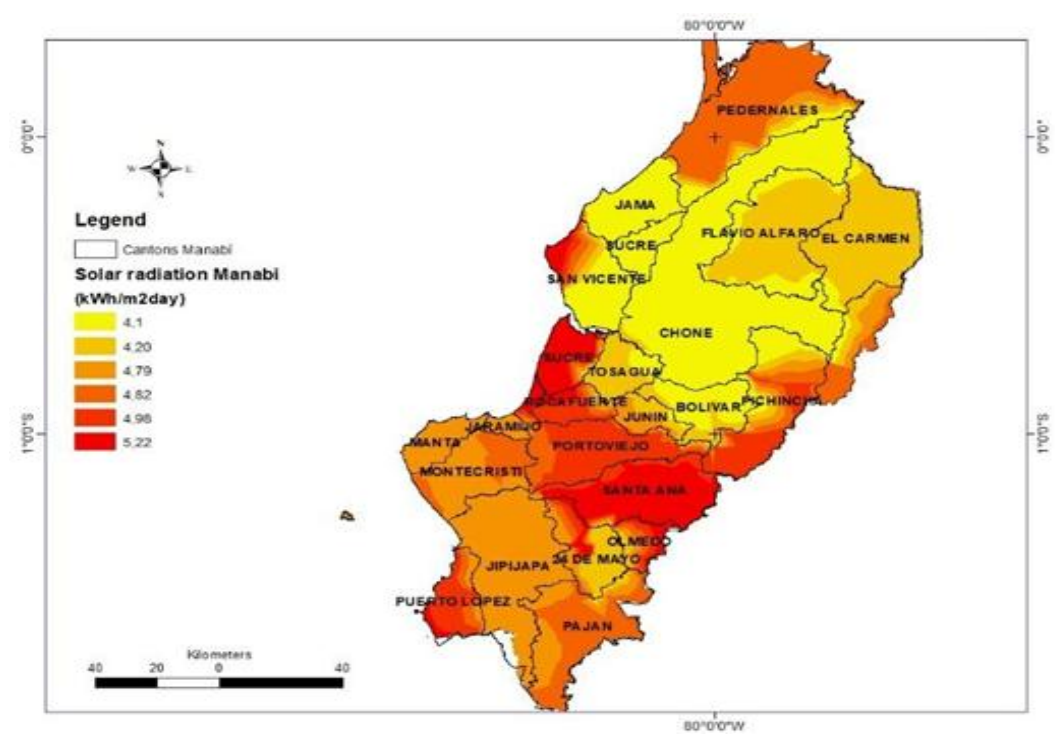

Figure 1. Solar potential in the province of Manabí 
As can be seen in the canton, radiation levels are high, this guarantees that for each $\mathrm{kWp}$ of photovoltaic installed, between 31.5 MWh and 31.9 MWh of electricity can be generated during the cycle life of the technology, with an average cost estimated between 8 and 10 cents per kWh generated, which represents a very competitive price with any of the energy sources available in the territory. A considerable level of solar radiation affects the territory of the province of Manabí. However, this endogenous natural resource is not used adequately for energy purposes for the benefit of society. The lack of information to develop research related to this natural resource and the form of its use is one of the barriers that slow the development of technologies, using the Geographic Information System a portal is being developed that collects the information that can be used in the energy planning of the provincial territory (MARTíNEZ et al., 2019). Table 1 shows the statistical information of the annual average solar potential and by months of the year.

Table 1

Annual average Manabí province solar potential

\begin{tabular}{|c|c|c|c|c|c|c|c|c|c|c|c|c|c|}
\hline concept. & $\begin{array}{l}\text { Prom } \\
\text { annual }\end{array}$ & January & Febre & March & April & May & June & July & August & Sept & Oct & Nov & Dec \\
\hline Potential & (kWh / & day) & & & & & & & & & & & \\
\hline Solar & 4,601 & 4,982 & 4,977 & 5,526 & 5,409 & 4,867 & 3,930 & 3,753 & 4,056 & 4,312 & 4,269 & 4,367 & 4,758 \\
\hline
\end{tabular}

It can be seen in the table the radiation levels are between 3.9 and $5.5 \mathrm{kWh} / \mathrm{m} 2$ day, which are high values that can allow generating energy in almost the entire territory of the province in the entire year. Knowing the annual average daily solar potential, the normalized productivity estimate can be made at the site where the technology is to be installed. This information is vital to calculate the photovoltaic power that could be installed, as well as to estimate the energy productivity of the System.

At present, Ecuador intends to give a boost in the industrialization of the economy, which implies the progressive increase in electricity demand, especially in sectors linked to industry, and as a guarantee of this new paradigm, it is committed to the change of the energy matrix (Osorio LL, 2013), which since its emergence in the 20th century was based on a strong thermal component based on the burning of oil.

At present, the political will to change the Ecuadorian energy matrix is focused on the articulation of a mainly hydraulic technical base, given the abundance of water resources in the national territory (Osorio LL, 2013), but the consequences associated with climate change can jeopardize the technical reliability of a system that depends practically on a single energy source, no matter how abundant it may be, so it is necessary to consider the use of other RES and thus diversify the system in order to achieve a technical base sustainable and the postulates embodied in the National Plan for Good Living 2013-2017 become a reality (Senplades, 2013).

The current problem lies in the need to study the search for energy alternatives that ensure the sustainable diversification of sources for the change of the energy matrix, that allow achieving high technical reliability and guaranteeing the quality of the electricity service, for which they must increase generation sources; save more expensive and polluting primary sources of energy; reduce losses; avoid new investments in technological infrastructure; favor the decentralization process in the planning and operation of the country's energy system. In this context, the emergence of the figure of the independent energy producer may be key, who, putting his responsibility and resources at stake, may be able to incorporate a greater relocation and regionalization of the economic activity linked to the generation of electricity, meaning his own time a democratic change in the control of resources and a break with the current centralized, polluting and unsustainable energy scheme. Creating a space in which to generate renewable electricity requires fixed expenses from the start that not just anyone can afford. In the long run, it is always profitable, but the state does not have the economic capacity to carry it out (Weisser \& Garcia, 2005; Omer, 2017).

\section{Energy planning in Portoviejo}

To carry out energy planning in Portoviejo, the environmental elements that affect land use were taken into account, and the areas that are considered invalid for making any investment were selected, for example, roads, rivers and streams, hydrographic basins, in which the regulations that prevent investments from being made in those territories were taken into account, in addition to the power lines, which must be taken into

Narváez, F. A. S., \& Castro, E. I. M. (2021). Energy planning with renewable energy sources. International Journal of Physical Sciences and Engineering, 5(3), 44-51. https://doi.org/10.53730/ijpse.v5n3.2941 
account for the connection of the systems. In figure 2, the spaces of the territory occupied by power lines are shown.

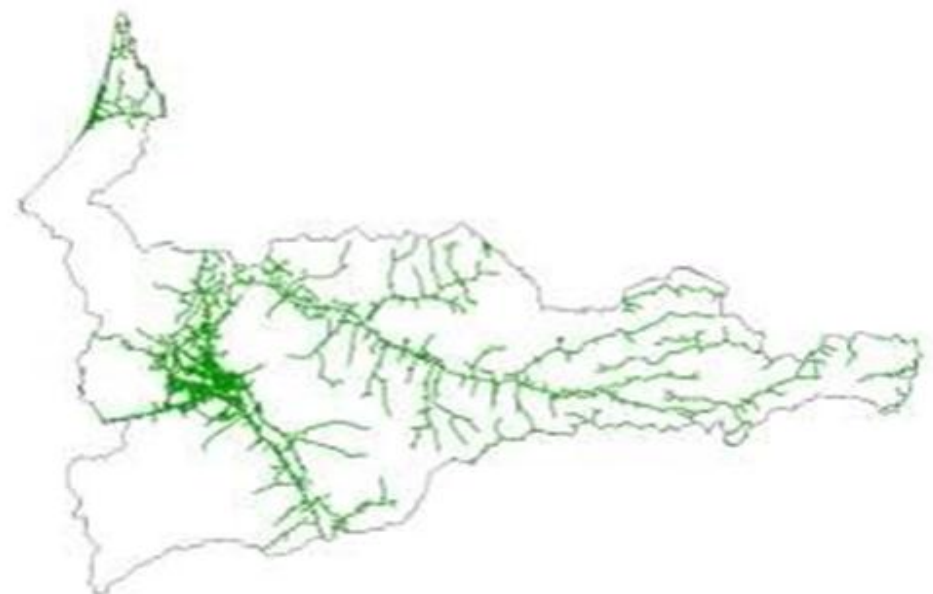

Figure 2. Power lines of the Portoviejo canton

\section{Viable areas}

The introduction of renewable energies to the country's energy development requires the design of an integrated planning model for energy resources, capable of combining economic development and sustainability. New energy planning formula that satisfies policies and economic interests, integrating energy, the economy, and the environment, combining energy production and saving, knowing the levels of demand that, due to their demands, can be satisfied with renewable energies and which must continue to be satisfied With the traditional systems in the state and residential sectors, the proximity of the generation with the consumers must be known, which favors the production of a new conscience of consumption, adjusted to the real possibilities offered by renewable energy systems. Develop a close vision of energy for citizens, increasing energy savings and efficiency adjusted to the consumption pattern.

The country is taking the first steps to introduce these sources of electricity generation, but their implementation has been slowed down by the lack of information and especially the lack of research on the resources available to the country. This is how the need for comprehensive studies on the different resources are imposed: water, solar, wind, geothermal, etc. that Ecuador has.

\section{Energy efficiency and sustainable development}

To improve energy efficiency and ensure that populations are committed to sustainable development, local actors and institutions do not have reliable and timely information, which makes it difficult to apply solutions for sustainable development. Government strategies must draw up strategies that help the development of an energy-saving community thinking and know the conditions that today cause conventional energy sources, in this sense the Technical University of Manabí has proposed a model of sustainable energy development based on the analysis of the renewable potential that exists in the territory, the care of the environment and the interaction with society, based on its needs and availability of resources, through the use of a geographic information system to manage a large volume of georeferenced data to generate maps, specifying the availability of endogenous energy resources, useful to design projects that seek the sustainability of the territory (Pérez et al., 2020).

To support the knowledge of the renewable potentials, the main rivers of the province have also been studied; an example of this can be observed in studies carried out in the canton of El Carmen, the settlements near the river for the use of the local resource, knowing that the Hydraulic energy is cheaper than the average price of thermal energy, in addition to the environmental benefit that the implementation of these projects entails for being clean energy (Posso, 2002), these criteria still prevail (Bravo, 2015). In the river De Oro, there are small hydraulic potentials that can be used to generate electricity; however, they have not been 
sufficiently studied, even though there are ways to make an integrated analysis of local energy sources (Rodríguez Borges et al., 2015). The flows of the De Oro River have been marginal from the energy point of view in recent decades like many other regions of Latin America (Ibañez Martin et al., 2020), which has impacted the progress of agricultural areas and the very quality of life of the inhabitants, mostly from poor strata. Currently, more than $5 \%$ of the population does not have electricity services, mainly in rural areas far from generation centers.

For local energy development, the influence of economic policies operated during energy transitions must be taken into account, and local solutions must be rescued, valuing the role of the territory and localities in the energy destination of society, a decentralized development model that is increasingly based on the consumption of local natural resources, where the impact on the environment is reduced. There is a need to embrace an energy development model that adopts as a paradigm the concepts associated with local development and the adequate use of endogenous resources (Gámez et al., 2021).

\section{Conclusion}

Renewable energies are presented as a highly effective solution not only for Ecuador but for the entire world. This type of energy, in addition to being practically inexhaustible, has a practically zero pollution effect and it is also possible to obtain clean energy at very low costs with projects that can be profitable and whose profitability increases when considered as "Clean Development Mechanisms". For the implementation of Renewable Energy, a socio-technological change will be required that will hardly be immediate, whose metamorphosis will demand innovation in both economic and social aspects. It is necessary to evaluate various renewable resources available, likewise, financing mechanisms must be identified, adequate regulations created, promote the commitment and acceptability of citizens, in addition, to establish a solid municipal structure that includes energy as one of its development axes. priority based on sustainable development

\section{Acknowledgments}

We thank the editors of the magazine who have allowed the publication of the paper. 


\section{References}

Aghaei, J., \& Alizadeh, M. I. (2013). Demand response in smart electricity grids equipped with renewable energy sources: A review. Renewable and Sustainable Energy Reviews, 18, 64-72. https://doi.org/10.1016/j.rser.2012.09.019

Battaglini, A., Komendantova, N., Brtnik, P., \& Patt, A. (2012). Perception of barriers for expansion of electricity grids in the European Union. Energy Policy, 47, 254-259. https://doi.org/10.1016/j.enpol.2012.04.065

Bravo, H. (2015). Energy and sustainable development in Cuba. Centro Azucar, 42(4).

Clastres, C. (2011). Smart grids: Another step towards competition, energy security and climate change objectives. Energy policy, 39(9), 5399-5408. https://doi.org/10.1016/j.enpol.2011.05.024

da Graça Carvalho, M. (2012). EU energy and climate change strategy. Energy, 40(1), 19-22. https://doi.org/10.1016/j.energy.2012.01.012

Gámez, MR, Pérez, AV, Viteri, CGFV, \& Quiroz, CAB (2021). Local energy development based on climate change mitigation. Brazilian Journal of Business , 3 (1), 975-992.

Ibáñez Martín, M., Guzowski, C., \& Maidana, F. (2020). Energy poverty and exclusion in Argentina: dispersed rural markets and the PERMER program. Revista Reflexiones, 99(1), 40-71.

Kezunovic, M., Pinson, P., Obradovic, Z., Grijalva, S., Hong, T., \& Bessa, R. (2020). Big data analytics for future $\begin{array}{lllll}\text { electricity } & \text { grids. Electric } & \text { Power } & \text { Systems } & \text { Research, 189, }\end{array}$ https://doi.org/10.1016/j.epsr.2020.106788

MARTÍNEZ, VA, RODRÍGUEZ, M., BRAVO, JJ, VÁZQUEZ, A., VALENCIA, JA, \& BOWEN, CA (2019). Implementation of a Geographic Information System for Sustainable Development at the Technical University of Manabí. ESPACIOS Magazine, 40 (39).

Omer, A. M. (2017). Sustainable development and environmentally friendly energy systems. International Journal of Physical Sciences and Engineering, 1(1), 1-39. https://doi.org/10.21744/ijpse.v1i1.2

Osorio, L. L (2013). The change in the productive matrix in Ecuador and its effect on foreign trade. Conference at the Pontificia Universidad Católica del Ecuador 2013, VI international week of administration, accounting and auditing.

Páez, A. (2010). Energy-urban transition: The Mexican case. Energy Policy, 38(11), 7226-7234. https://doi.org/10.1016/j.enpol.2010.07.053

Pérez, AV, Araus, WMS, Viteri, CGV, \& Gámez, MR (2020). A model for sustainable energy development. The university, geography and endogenous resources / A model for sustainable energy development. The university, geography and endogenous resources. Venezuelan Geographical Magazine , 61 (1), 220-234.

Posso, F. (2002). Energy and environment: past, present and future. Part two: Energy system based on alternative energies. Geo-teaching , 7 (1-2), 54-73.

Rodríguez Borges, C. G., Sarmiento Sera, A., \& Rodríguez Gámez, M. (2015). Model for the comprehensive assessment of rural electrification technologies. Energy Engineering, 36(2), 136-145.

Senplades. (2013). National Plan for Good Living 2013-2017.

Tarroja, B., Forrest, K., Chiang, F., AghaKouchak, A., \& Samuelsen, S. (2019). Implications of hydropower variability from climate change for a future, highly-renewable electric grid in California. Applied Energy, 237, 353-366. https://doi.org/10.1016/j.apenergy.2018.12.079

Trujillo, A. E. G. (2019). Harmonics influence on power and energy measurements. International Journal of Physical Sciences and Engineering, 3(1), 32-41. https://doi.org/10.29332/ijpse.v3n1.254

Vázquez-Rowe, I., Reyna, J. L., García-Torres, S., \& Kahhat, R. (2015). Is climate change-centrism an optimal policy making strategy to set national electricity mixes?.Applied energy, 159, 108-116. https://doi.org/10.1016/j.apenergy.2015.08.121

Weisser, D., \& Garcia, R. S. (2005). Instantaneous wind energy penetration in isolated electricity grids: concepts and review. Renewable energy, 30(8), 1299-1308. https://doi.org/10.1016/j.renene.2004.10.002

Yadoo, A., \& Cruickshank, H. (2012). The role for low carbon electrification technologies in poverty reduction and climate change strategies: A focus on renewable energy mini-grids with case studies in Nepal, Peru and Kenya. Energy Policy, 42, 591-602. https://doi.org/10.1016/j.enpol.2011.12.029 


\section{Biography of Authors}

\begin{tabular}{|l|l||}
\hline & $\begin{array}{l}\text { Félix Antonio } \\
\text { He graduated as an electrical engineer, graduated as a civil at the Universidad } \\
\text { Técnica de Manabí he is currently doing a postgraduate degree in electrical power, } \\
\text { code https://orcid.org/0000-0003-1470-6672. } \\
\text { Email: felixsolorzano1978@gmail.com }\end{array}$ \\
\hline $\begin{array}{l}\text { Edgar Iván Moreno Castro } \\
\text { Ecuadorian nationality, was born in the city of Santo Domingo on March 14, 1987, } \\
\text { graduated as an electrical engineer on January 13, 2013, at the Technical } \\
\text { University of Manabí, he is currently doing a postgraduate degree in electrical } \\
\text { power, code https://orcid.org/0000-0003-3803-3513. } \\
\text { Email: edgarmoreno1403@gmail.com }\end{array}$ \\
\hline
\end{tabular}

Narváez, F. A. S., \& Castro, E. I. M. (2021). Energy planning with renewable energy sources. International Journal of Physical Sciences and Engineering, 5(3), 44-51. https://doi.org/10.53730/ijpse.v5n3.2941 